\title{
Judicial Protection under EAC Law: Direct Actions
}

\author{
John Eudes Ruhangisa
}

\subsection{Introduction}

Judicial protection entails the guarantees offered by a legal order to the people as they individually or collectively enforce their rights or seek redress through litigation in the courts of law. In any country, rights on paper conferred by various legislation have little meaning if they cannot be claimed by individuals and be enforced via available legal remedies.

The concept of judicial protection at national level as well as at international level encompasses various elements such as access to justice, the right to an effective remedy and principles of fair trial and due process of law. ${ }^{1}$

The common place where redress or legal remedies can be sought in a national legal order is the court of law. Democratic States therefore are under obligation to provide to the citizens adequate procedural tools for the realization of this mechanism. The East African Community (EAC) as a democratic regional organization which aspires to become a political federation is no exception and therefore, the EAC has developed mechanisms to enable individuals to realize their rights afforded to them under the Treaty for the Establishment of the East African Community (Treaty).

\subsection{An Overview}

In any active partnership, differences, disagreements or disputes are bound to happen in the course of realizing the agreed terms by the partners. Inevitably, partners in the integration agenda just like partners in a business venture may find themselves disagreeing on some matters and such disagreement necessitates the intervention of a neutral person as an arbiter. The dispute requiring settlement may be between the member countries inter se, or the institutions of the organization against a member country or an individual citizen. In many

1 For a discussion on judicial protection see: Linda Mario Ravo "The Role of the Principle of Effective Judicial Protection in the EU and its Impact on National Jurisdictions", Ph.D Thesis, University of Trieste, pp. 102-104. 
cases the disputes involve the citizens of the member countries and their governments or citizens among themselves in the course of interacting and enjoying the benefits of integration as provided by the Treaty.

Since disagreements among active partners cannot be avoided, it is important that the contracting partners put in place a mechanism to deal with this eventuality when circumstance deems it necessary.

Being mindful of the above stated possibility and in anticipation of there being disagreements, the founding fathers of the EAC made a provision for the arbiter in the Treaty. ${ }^{2}$ The East African Court of Justice (EACJ) was specifically created as one of the ten organs of the Community, ${ }^{3}$ and was charged with settlement of disputes arising out of the Treaty. ${ }^{4}$ Its major responsibility is to ensure the adherence to law in the interpretation and application of and compliance with the Treaty. The EACJ therefore, as the judicial organ of the Community, provides judicial protection to the citizens of East Africa through judicial pronouncements on matters that are brought before it by anyone seeking judicial protection on a point of EAC law and within the EAC framework.

Indeed the crucial role that both the laws and the courts play in the daily lives of citizens, and the crucial role that legal norms play in managing relationships that exist between sovereign states that intend to deepen or widen their relationship in the form of regional integration, cannot be overemphasized. ${ }^{5}$ Undoubtedly, the Court plays a crucial role in the process towards integration of the EAC. This role can be effectively realized through the Court's effective and efficient execution of its mandate as an arbiter in dispute resolution, thereby contributing to confidence building in the region. Invariably the Court by playing its role effectively is expected to enhance the observance and upholding of human rights through good governance and democratic institutions in the region. All these aspirations and objectives must be reflected in the ways the Court conducts its activities including the quality of its judgments and the arbitration awards.

The concept of judicial protection is reflected in the Treaty where it creates legal actions in order that the Partner States, Secretary General, Council of

2 Chapter Eight of the Treaty for the Establishment of the East African Community (The Treaty) is dedicated to the East African Court of Justice.

3 Articles 9 (1) (e) of the Treaty op. cit.

4 Article 23 (1) and 27 (1) of the Treaty op. cit.

5 RUHANGISA, John, "Establishing Independent and Effective Regional Courts: Lessons for the SADC Region from the EAC and ECOWAS", A Paper presented during the SADC Regional Colloquium on the SADC Tribunal, Johannesburg, South Africa, 12th-13th March 2013. 
Ministers, legal and natural persons and employees of the Community are able to approach the Court for a remedy. These include

(a) A situation where a Partner State or an organ or institution of the Community fails to fulfil an obligation under the Treaty or infringes a provision of the Treaty; 6

(b) An action to question the legality of any Act, regulation, directive, decision or action of a Partner State for being ultra vires or unlawful or an infringement of the provisions of the Treaty or any rule of law relating to its application or that it amounts to a misuse or abuse of power; ${ }^{7}$

(c) Where a Partner State has failed to fulfil an obligation under the Treaty or infringes a provision of the Treaty (not by natural persons); ${ }^{8}$

(d) An action to question the legality of any Act, regulation, directive, decision or action of a Partner State or an institution of the Community whenever such Act, regulation, directive, decision or action is unlawful or infringes the provisions of Treaty; ${ }^{9}$

(e) Whenever a dispute arises between the Community and its employees concerning the terms and conditions of employment of the employees of the Community or the application and interpretation of the staff rules and regulations and terms and conditions of service of the Community. ${ }^{10}$

The only remedy available in the above actions is court declaratory orders, ${ }^{11}$ except for actions concerning terms and conditions of service of employees of the Community until when other original, appellate, human rights and other jurisdiction will be determined by the Council at a suitable subsequent date and a protocol concluded to that effect. ${ }^{12}$

Subject to the provisions of Article 27 of the Treaty, any person who is resident in a Partner State may refer for determination by the Court, the legality of any Act, regulation, directive, decision or action of a Partner State or an institution of the Community on the grounds that such Act, regulation, directive,

6 Article 28 (1) of the Treaty op. cit.

7 Article $28(2)$ Ibid.

8 Article 29 Ibid.

9 Article 30 of the Treaty op. cit.

$10 \quad$ Article 31 Ibid.

11 Articles 23(1), 27(1), 33, 34, and 38 of the Treaty.

12 Article 23(2) of the Treaty. 
decision or action is unlawful or is an infringement of the provisions of this Treaty. ${ }^{13}$

The actions that can be brought before the EACJ for judicial remedies include: actions for interpretation of the Treaty and Community laws, action for annulment, actions for liability, EAC employees' conflict, reference by national courts on points of EAC law, infringement proceedings, arbitration and advisory opinions. In all these actions, there is no requirement for exhaustion of local remedies as is the case with many regional and international courts. $^{14}$

\subsection{The Action for Annulment}

An action for annulment is a legal procedure brought before the EACJ questioning the legality of an act/decision by a Partner State or by the organs/institutions of the Community and seeking the review of such acts or decisions. The Court shall annul the act concerned if the impugned act or decision is found to be contrary to the Treaty or any of the Community laws. Such action must be based on the violation or breach of the provisions of the Treaty by either the Partner State, or the organ or institution of the Community. This kind of intervention can be equated to judicial review under Common Law whereby the Court has power to issue the prerogative orders of mandamus and certiorari against the government, institutions of government or against the agents of government and people in service of the public institutions.

While the legislative and executive organs work towards the creation of an environment which furthers political integration by enacting Community laws and adopting policies for the implementation of these laws, the judicial organ plays the crucial role of interpreting the Treaty and other Community laws and in ensuring respect for the founding principles of the Community. The EACJ has on several occasions been called upon to invoke its powers to interpret the Treaty and other Community laws with a view to measuring the acts of the Partner States or the organs/institutions of the Community against the dictates of the Treaty or Community law. The first case to test the waters in this area originated from the East African Legislative Assembly (the Assembly), in which three members of the Assembly approached the Court in the famous

\footnotetext{
13 Article 30 (1) of the Treaty op. cit.

14 Ibid.
} 
case Callist Andrew Mwatela and Others v. The East African Community. ${ }^{15}$ This was also the first case to be filed with the EACJ.

What gave rise to the dispute in Callist Andrew Mwatela were four Private Members' Bills ${ }^{16}$ which were pending before the Assembly. The Council of Ministers decided that they could take over the Bills seeing as they were policy oriented Bills and had implications on the Partner States sovereign interest. The Sectoral Council for Legal and Judicial Affairs to which the Council forwarded the Bills for their expert input, decided that, rather than having legislative acts enacted by the Assembly, protocols would be sufficient and that the two Bills should be withdrawn from the Assembly. The Secretary General communicated this to the Speaker. Aggrieved by this Council decision, three members of the Assembly brought the case before the EACJ seeking the annulment of the report of the Sectoral Council on Legal and Judicial Affairs including all its decisions, directives and actions contained in or based on it. With reasoned analysis of the issues the Court made the following specific findings, considerations, conclusions and holdings:

1. That the Council is empowered under Article 14 of the Treaty to establish Sectoral Councils from among its members only. Membership of the Council under that Article is restricted to Ministers.

2. (a) That for the Council of Ministers to be properly constituted, it must comprise the stipulated quorum of the "representatives of all Partner States", in conformity with Rule 11 of the Rules of Procedure of the Council

(b) That the Rule applies to Sectoral Council as well, since the decisions of Sectoral Council are deemed to be decisions of the Council of Ministers under Article 14(3) ( $i$ ) of the Treaty. Accordingly the establishment of the Sectoral Council of September 2005, was inconsistent with the provisions of Article 14(3)(i) of the Treaty.

3. That the meeting of 13th-16th September, 2005 was not lawful meeting of a Sectoral Council; and decisions it handed down in respect of the two Bills were not valid decisions of the Sectoral Council. Therefore the Court ordered annulment of the decisions of the purported "Sectoral Council" However, since that Sectoral Council had been in place from 2001 and had

15 Reference No. 1 of 2005.

16 The East African Community Trade Negotiation Bill, The East African Community Budget Bill, The East African Community Immunities and Privileges Bill, and The Inter-University Council for East Africa Bill. 
undoubtedly made a number of decisions which it would be unwise to disturb, the Court was of the considered opinion that this was a proper case to apply the doctrine of prospective annulment-which the Court held to be "good law and practice". Accordingly, the Court ordered that its annulment of this particular Sectoral Council report would not have retrospective effect.

4. (a) The Treaty does not provide for the members of the Council or the Sectoral Council to be represented at meetings by non members

(b) This was deliberate, to avoid distortion of the elaborate structural hierarchy of representation of Partner States at the different levels in the organizational framework of the Community, in order to uphold the objective of the separation of the functions of the different organs of the Community.

5. (a) Ministers of Partner Stats cannot appoint persons who are not Ministers to attend meetings of Sectoral Councils or those of the Council purportedly on their behalf.

(b) To do so would be to make inroads into the very clear words of Article 13 of the Treaty.

6. (a) Although the composition of the Council is established under Article 13 of the Treaty, the total membership is not readily ascertainable, since it is only the membership of Ministers responsible for Regional Cooperation which is static and ascertainable.

(b) Apparently membership of additional Ministers is determined by the agenda of a particular meeting of the Council. A more transparent way of knowing the composition of the Council Members should be evolved, to avoid uncertainty and disputes.

Following the Court's findings, the Treaty was amended to legalize the status of Attorney Generals in the Sectoral Council for Legal and Judicial Affairs by formally recognizing them as members of the Council. After the amendment, the Treaty read:

The Council shall consist of:

(a) The Minister responsible for East African Community affairs of each Partner State;

(b) Such other Minister of the Partner States as each Partner State may determine; and

(c) The Attorney General of Each Partner State ${ }^{17}$

17 Article 13 of the Treaty [Emphasis added]. 
Invariably, none of the subsequent requests for annulments was successful to obtain an order with retrospective effect. For example, in the case of East African Law Societyv. The Attorney General of Kenya \& 3 Others, ${ }^{18}$ the Court was asked whether the amendments to the Treaty as carried out by the Summit could be stopped. The Court declined to invalidate the amendments and instead declared that the decision on the requirement of involvement of people in the Treaty amendment process shall have prospective application.

In essence the Court hesitated to nullify the impugned amendments but warned the Partner States not to repeat the same mistake in future, and if they did, such amendments would ipso facto be null and void. This is technically known as prospective annulment ${ }^{19}$ or prospective overruling ${ }^{20}$ or the doctrine of temporary validity. Under normal circumstances nullification by the court is prospective, meaning that after the nullification of the action or the law, such act or law so nullified by the court becomes void and of no consequence from the date the court declares the impugned act or law null. This means the impugned affairs remain undisturbed even after the date when the court makes the declaration. It has the effect of outlawing new similar future acts. The doctrine was devised by the Supreme Court of the United States in the case of Linkletter v. Walker, 381 US (1965) 618 to alleviate the inconveniences which would have resulted from its new decision which was a departure from its previous ruling that impugned the law was constitutional. Likewise the EACJ was mindful of the fact that the Sectoral Council for Legal and Judicial Affairs had illegally taken many decisions of a policy nature concerning the development of the Customs Union. These decisions would be affected and

18 The Applicants filed this Reference challenging the legality of the process for the December 2006 Amendments of the EAC Treaty. The Applicants challenge was not directed to the substance of these amendments. Rather, they challenged the extra-ordinary hasty manner and the impropriety of the amendment process as being an infringement of Articles $1,5,6,7,8,9,11,26,38$ and 150 of the Treaty: namely, failure to have the mandatory 90 days period for Partner States' comments under Article 150(4) and (5): amending the Treaty while the EACJ was still seized of a live case on the matter (i.e. Reference No. 1 of 2006); and exclusion from the Amendment process of other EAC Organs, State governments, and the people and registered of East Africa.

19 The same approach was adopted by the Court in the case of Callist Andrew Mwatela and Others vs The East African Community, Reference No. 1 of 2005 when it was called upon to nullify the report of the Sectoral Council on Legal and Judicial Affairs including all its decisions, directives and actions contained in or based on it.

For a discussion on prospective overruling see the decision of the Supreme Court of Uganda in the case of The attorney General vs Paul K. Ssemogerere and Hon. Zachary Olum, Constitutional Appeal No. 3 of 2004 at pages 138-139. 
serious inconvenience would be caused to the advanced stage that had been reached in negotiating the Customs Union Protocol if the EACJ would have nullified all such decisions. ${ }^{21}$

\subsection{The Action for Interpretation of the Treaty}

In interpreting laws, courts play an important role complementing that of legislators in as far as they give clear and detailed explanations of the content and spirit of the laws. In a context of a regional organization aimed at full integration of Partner States as is the case with the EAC, the judicial pronouncements and interpretation of the Community laws assist the policy makers to have a common understanding of these laws in order to take informed decisions consistent with their spirit during the implementation stage. The EACJ has actively played this role as it transpires from its jurisprudence so far developed.

In the case of Callist Andrew Mwatella \& 2 others $v$. EAC, ${ }^{22}$ discussed above in relation to annulment, the applicants also requested the Court to interpret various provisions of the Treaty against the actions and decisions of the Council of Ministers and the Sectoral Council for Legal and Judicial Affairs. As outlined, the Council of Ministers and the Secretariat had illegally assumed control over Assembly-led Bills. However, the Council had also purported to withdraw four Private Members' Bills from the Assembly and therefore the application to the EACJ questioned the right of the Council to delay the presentation of the Bills to the House.

The Court found that the Sectoral Council on Legal and Judicial Affairs was not constituted per Treaty, in particular Article 14 which provided that the Council of Ministers shall 'establish from among its members' Sectoral Councils and that Sectoral Council members are restricted to 'ministers' as defined by the Treaty. The Court found that Kenya and Tanzania were represented by non-ministers at the disputed meeting of the 13th to 16th September 2005 and, therefore the meeting was not properly constituted and did not amount to a lawful Sectoral Council meeting. In this regard, its decision regarding the two Bills was ipso facto invalid.

21 See for the options to limit the retrospective effect of an annulment under EU law EU Chapter 8.

22 Application No. 1 of 2005. See also the case of Christopher Mtikilav. The Attorney General of the United Republic of Tanzania and the Secretary General of the East African Community, Reference No. o8 of 2007. 
On another issue the Court interpreted Article 59 (1) to the effect that any Member of the Assembly may introduce a Bill in the House as the Council does not have exclusive legislative initiative to introduce Bills in the Assembly. The Court held that the Assembly owns all Bills once in the Assembly, whether they came initially by way of Private Members' Bills or Community Bills. As such, permission of the Assembly would be required for withdrawal of any Bill and such approval must be sought and obtained through a motion passed by the Assembly. The Court found that the Bills were already in the Assembly, so could not be withdrawn by the Council of Ministers as purportedly done and that all the Council could do was to delay the debate but could not withdraw the Private Members' Bills.

On the issue concerning the relationship of the Council and the Assembly on legislation, the Court held that the decisions of the Council even on policy issues have no place in areas of jurisdiction of the Summit, Court and the Assembly. ${ }^{23}$ It held that the Assembly is a creature of the Treaty like the other organs of the Community and its competence is only on matters conferred upon it by the Treaty as with all Community organs. In this regard, the Assembly could only legislate on matters on which the Partner States had surrendered sovereignty or part thereof to the EAC.

By interpreting these Articles of the Treaty, the Court provided guidance for future operations of the affairs of the Community by its organs and institutions. The Court boldly told the Ministers and Attorney Generals that they had overstepped their boundaries which was not acceptable in any democratic institution.

Another significant case that was brought to the EACJ seeking interpretation of the Articles of the Treaty vis- $\grave{a}$-vis the actions of a Partner State was Anyang' Nyong'o \& others $v$. The Attorney General of Kenya \& Others. ${ }^{24}$ The main contention in this reference was whether Kenya's process of electing the nine persons deemed to be its members in the Assembly and the rules of the Kenya National Assembly for Assembly elections infringed Article 50 of the EAC Treaty.

The EACJ considered the possible meanings of the expression "the National Assembly shall elect" as stated in Article 50 of the Treaty. The Court found that it can only mean "shall choose by vote" taking the ordinary meaning of the phrase and that reference to "democratic election of persons to political office" is understood to mean election by voting. Furthermore, the Court found that this interpretation of the meaning of "elect" is borne out by the practice in each Partner State of electing the Speaker and Deputy Speaker in the National

23 Article 14 (3) (c) and Article 16 of the Treaty, op. cit.

24 Reference No. 1 of 2006. 
Assembly through voting. In all Partner States, the National Assembly executes the function of electing Speaker and Deputy Speaker by voting in one form or another and the extent of discretion of the National Assemblies is to determine what procedure should be applied for the voting. The Court held that the bottom line for compliance with Article $5^{0}$ is that the decision to elect is a decision of and by the National Assembly not another caucus.

Finally, on whether the Kenyan rules complied with Article 50, the Court held that the election rules partially comply with Article 50 of the Treaty in so far as they provide for proportional representation of political parties. However, there was a significant degree of non-compliance in the failure to make a provision for gender and other special interest representation. The major deviation found in the Kenyan rules was the non-provision for election. The Court held that the election rules and actual process was the antithesis of an election, as the rules "deemed" the nine elected in order to circumvent the express Treaty provision.

\section{$7 \cdot 5$}

\section{EAC-Employee Conflicts}

The jurisdiction of the EACJ includes hearing and determining disputes between the Community and its employees which arise out of the terms and conditions of their employment; the application and interpretation of the staff rules and regulations; or the terms and conditions of service of the Community. ${ }^{25}$ This is another area where the Court has not performed well in terms of statistics of cases that have been filed and determined. As of November 2015, only two cases, Alloys Mutabingwa v. the Secretary General of the East African Community ${ }^{26}$ and Angela Amudo v. the East African Community, ${ }^{27}$ had been filed.

The former case concerned the claim by Mr Alloys Mutabingwa following the refusal by the Secretariat to compensate him full remuneration for the remainder of contract, which had been cut short by the EAC. Such remuneration was a mandatory requirement under Rule 96(3) of the EAC Staff Rules and Regulations. However, the case could not go for trial as the claimant withdrew his claim.

\footnotetext{
25 Article 31 of the Treaty, op. cit.

26 Claim No. 1 of 2011.

27 Claim No. 2 of 2012.
} 
In the latter case, Ms Angela Amudo sought a declaration concerning the tenure of appointment given to her which was initially for a period of 20 months with subsequent periodical extensions of the appointment up to 3oth April 2012. Amudo submitted that such tenure was ultra vires, considering the powers of the Secretary General and his deputies, and also inconsistent with the Staff Rules and Regulations of the Respondent, and as such she was entitled to a contract of employment for a period of 5 years from the date of assumption of duty renewable for another 5 years. The claim was heard by the Court and judgment was partly entered in her favour. Ms Amudo appealed in relation to the part of her claim that she lost, however, the Appellate Division dismissed the appeal and allowed the cross-appeal on the basis that the Appellant's position was not an established position in the Community and therefore Ms Amudo could not have been regarded as a member of staff under the Staff Rules and Regulations.

\subsection{Direct Appeals from Other Courts on Points of EAC Law}

The jurisdiction of the Court as presently constituted does not include direct appeals from national courts. ${ }^{28}$ Instead, the Treaty prescribes the jurisdiction of the Court to include references, by national courts, for preliminary ruling when a question is raised before any court or tribunal of a Partner State concerning the interpretation or application of the provisions of the Treaty or the validity of the regulations, directives, decisions or actions of the Community. ${ }^{29}$ The procedure operates so that national courts or tribunals shall, if they consider that a ruling on the question is necessary to enable it to give judgment, request the EACJ to give a preliminary ruling on the question.

Furthermore, under the proviso to Article 27(1), the Court's jurisdiction to interpret the Treaty shall not include the application of any such interpretation to the jurisdiction conferred by the Treaty on organs of the Partner States. This Article should be read together with Article 33 which reads-

\footnotetext{
28 Such direct appeals should be distinguished from the preliminary questions procedure, discussed in Chapter 8, which allows national courts to ask questions to the EACJ during national proceedings, but does not allow parties to appeal to the EACJ.

Article 34 of the Treaty, op. cit.
} 
(1) Except where jurisdiction is conferred on the Court by thisTreaty, disputes to which the Community is a party shall not on that ground alone, be excluded from the jurisdiction of the national court of the Partner States.

(2) Decisions of the Court on the interpretation and application of this Treaty shall have precedence over decisions of national courts on a similar matter.

The Court seems to have concurrent jurisdiction with national courts on the interpretation of the Treaty, but decisions of the Court take precedence over decisions of the national courts. This position, as it currently stands, may be a breeding ground for confusion. The EACJ in The East African Law Society and 4 Others $v$. The Attorney General of Kenya and 3 Others, ${ }^{30}$ made the following pertinent observation on this issue-

By the provisions under Articles 23,33(2) and 34, the Treaty established the principle of overall supremacy of the Court over the interpretation and application of the Treaty, to ensure harmony and certainty. The new (a) proviso to Article 27; and (b) paragraph (3) of Article 30, have the effect of compromising that principle and/or of contradicting the main provision. It should be appreciated that the question of what "the Treaty reserves for an institution of a Partner State" is a provision of the Treaty and a matter that ought to be determined harmoniously and with certainty. If left as amended the provisions are likely to lead to conflicting interpretations of the Treaty by national courts of the Partner States.

Also in Prof. Peter Anyang' Nyongo and 1o Others v. The Attorney General of Kenya and 2 Others and Abdirahim Haitha Abdi and 11 Others ${ }^{31}$, the Court had this to say-

The purpose of these provisions is obviously to ensure uniform interpretation and avoid possible conflicting decisions and uncertainty in the interpretation of the same provisions of the Treaty. Article 33(2) appears to envisage that in the course of determining a case before it a national court may interpret and apply a Treaty provision. Such envisaged interpretation however, can only be incidental. The article neither provides for nor envisages a litigant directly referring a question as to the

$30 \quad$ Reference No. 3 of 2007.

$31 \quad$ Reference No. 1 of 2006. 
interpretation of a Treaty provision to a national Court. Nor is there any other provision directly conferring on the national Court jurisdiction to interpret the Treaty.

It is important that this uncertainty in the Treaty provisions should be made clearer by amending the Treaty as appropriate. Therefore the Treaty, protocols and any Community law are the core generators of the work of the Court, and the Court can entertain any dispute arising out of these instruments. However, a continuing number of protocols contradicting the position of the Treaty have been enacted. Other parallel dispute resolution mechanisms (national courts and quasi-judicial bodies) have been established. For instance, Article 41(2) of the EAC Customs Union Protocol which deals with dispute settlement, establishes committees to handle disputes arising out of the Protocol and gives these committees finality in determining the disputes. The Court is left out and therefore denied a role in this process except if a party challenges the decision of the committee on grounds of fraud, lack of jurisdiction or other illegality. Again, under Article 54(2) of the Common Market Protocol, jurisdiction to entertain Common Market related disputes has mainly been given to national courts. At the same time Article 33(2) of the Treaty recognizes the EACJ's decisions on the interpretation of the Treaty and Community law as being superior to a national courts decision on the same matter. Since the EACJ does not form part of the hierarchy of the national judicatures, the Common market related dispute to be handled by national institutions will also follow the relevant national court system in case a party seeks to appeal against the decision of such national institution. This tendency of the Partner States to oust the jurisdiction of their own joint Court, is not conducive to the integration agenda. It has the effect of undermining the Court itself and causing confusion in the development of the uniform regional jurisprudence. ${ }^{32}$

\subsection{Appeals as a Remedy}

The Treaty provides that appeals from judgments and orders of the First Instance Division shall lie to the Appellate Division. ${ }^{33}$ However, there are two areas in the Treaty where such a mechanism may not be appropriate: firstly, on matters of referral of certain disputed questions from the national courts to

32 Compare in this regard also the rulings of the CJEU defending its ultimate authority as final arbiter of EU law, also to protect the unity of EU law, as discussed in EU Chapter 4. 
the EACJ ${ }^{34}$ and secondly, on matters of request for advisory opinions on questions of law arising from the Treaty. ${ }^{35}$

As alluded to earlier a national court or tribunal before which a question arises as to the interpretation or application of the Treaty, is required to request the EACJ to give a preliminary ruling on the matter, in order to enable the national court or tribunal before which the question has arisen to give its judgment on the parent matter. Where should such a referral go to, First Instance Division or Appellate Division? The Court has taken the initiative and invoked its rule-making powers under Article 42 of the Treaty by amending the EACJ Rules of Procedure and introduced Rule 76 to address this issue. Rule 76 (1) provides as follows-

A request by a national Court or tribunal of a Partner State concerning the interpretation or application of the provisions of the Treaty or validity of any regulations directives, decisions or actions of the Community pursuant to Article 34 of the Treaty shall be lodged in the Appellate Division by way of a case stated.

This may be a stop-gap measure, however, it is imperative that proper jurisdictional boundaries are provided for in the Treaty itself.

To date the national referral jurisdiction has remained essentially dormant in the EACJ with only two referrals from the High Court of Kenya and High Court of Uganda having been filed so far in the registry of the EACJ. ${ }^{36}$

The potential for referral is overwhelming, however, unfortunately, that potential has not been utilised. This failure cannot be attributed to a scarcity of disputed questions in the Partner States' national courts. The paucity of referrals is most likely due to various factors including lack of knowledge and non-awareness concerning the availability of this mechanism. The EACJ, national courts as well as the Bar Associations across the region have to sensitize the litigating public and all other concerned stakeholders about this jurisdiction.

34 Article 34 of the Treaty, Ibid. See also Rule 76 (1) of the East African Court of Justice Rules of Procedure.

35 Article 36 of the Treaty, op. cit. See also Rule 75 (1) of the East African Court of Justice Rules of Procedure.

36 See on this point also chapter 8 , as well as the very different situation in the $\mathrm{EU}$ as set out in Eu Chapter 8. 
In the European Union, referrals for preliminary rulings from national courts do make up a significant part of the CJEU's workload. ${ }^{37}$ Thus, the jurisprudence of the European Court has seeped down and saturated the roots of the national courts of all European Member States.

\subsection{Infringement Proceedings}

All proceedings in the EACJ require the Court to interpret either the Treaty or other Community laws in order to determine the issues before it. Infringement proceedings like other actions involve the interpretation of the law vis-à-vis the impugned action. A significant number of actions for infringement in the EACJ have largely involved the examination of the facts relating to adherence to the principles of democracy, the rule of law, promotion and protection of human and peoples' rights.

The regional cooperation put in place under the Treaty is peoplecentered and market driven. ${ }^{38}$ If democracy means the rule of the people by the people, and is one of the fundamental principles of the EAC, then the EAC working strategy must focus on participation of all social groups from the bottom to the top.

When it was asked to consider if by reason of failure to carry out wide consultations within Partner States on proposals for amendments, the process constituted an infringement of the Treaty in any way, the Court found that:

It is common knowledge that the private sector and civil society participated in the negotiations that led to the conclusion of the Treaty among the Partner States and, as we have just observed, that they continue to participate in the making of Protocols thereto. Furthermore, as we noted earlier in this judgment, Article 30 entrenches the people's right to participate in protecting the integrity of the Treaty. We think that construing the Treaty as if it permits sporadic amendments at the whims of officials without any form of consultation with stakeholders would be a recipe for regression to the situation lamented in the preamble of "lack of strong participation of the private sector and civil society" that led to the collapse of the previous Community. ${ }^{39}$

$37 \quad$ See the discussion in EU Chapter 8.

38 Treaty, Article 7 (1) (a).

39 East Africa Law Society and 4 others v. Attorney General of Kenya and 3 others, type written judgment p. 30 . 
The Court went on to conclude that:

[F]ailure to carry out consultation outside the Summit, Council and the Secretariat was inconsistent with a principle of the Treaty and therefore constituted an infringement of the Treaty $(. ..) .^{40}$

As regards, the principle of promotion and protection of human and peoples' rights, it must be noted that for any regional court to be seen as an integrating institution, it has inter alia to facilitate the integration process through the recognition of the rights of individuals.

Although explicit human rights jurisdiction is yet to be operationalized, the Court has been courageous enough to ensure that basic rights of individuals are respected. On more than one occasion, the Court has had to consider preliminary objections from defendants alleging lack of locus standi by individuals and legal persons. The Court has consistently upheld that individuals and legal persons have access to the Court under Article 30 of the Treaty, ${ }^{41}$ which is a basic right to the regional justice mechanism enabling the peoples to "participate in protecting the integrity of the Treaty."42 An infringement of the rights of the citizens of East Africa by the Partner State or by the organs or institutions of the Community is therefore actionable in the EACJ. However, the Court has strictly entertained such proceedings if and only if the impugned action or decision is by either the Partner State or the organ or institution of the Community. In the case of Modern Holdings (EA) Limited v. Kenya Port Authority, Reference No. 1 of 2008 the Court held that the Kenya Ports Authority lacked the authority to be sued because it was not an institution of the Community created under Article $9(2)$ of the Treaty or a surviving institution of the defunct EAC, instead it was created under section 3 of the Kenya Ports Authority Act as a statutory body with perpetual succession, a common seal and power to sue and be sued in its corporate name.

This ruling has been criticized as it is perceived that the Court "shot itself in the foot". Critics would have wished in the seemingly borderline cases like this that the Court would have made a finding that it had jurisdiction

$40 \quad$ As above p. 31.

41 Cases Prof. Peter Anyang' Nyong'o and Others v. Attorney General of Kenya and Others; Christopher Mtikilav. The Attorney General of the United Republic of Tanzania and the Secretary General of the East African Community and East Africa Law Society and 4 others $v$. Attorney General of Kenya and 3 others.

East Africa Law Society and 4 others $v$. Attorney General of Kenya and 3 Others. 
just like it did in James Katabazi \& 21 others $v$. The Secretary General of the East African Community \& Another, ${ }^{43}$ where even after finding that it had no direct jurisdiction, it still found a way of dealing with the matter. In Katabazi, the Court read the Treaty in toto and invoked the spirit of the Treaty instead of concentrating on the wording of the Treaty. The Court in that case said inter alia:

Does this court have jurisdiction to deal with human rights issues? The quick answer is: No it does not have.... It is very clear that jurisdiction with respect to human rights requires a determination of the Council and a conclusion of a protocol to that effect. Both of those steps have not been taken. It follows, therefore, that this Court may not adjudicate on disputes concerning violation of human rights per se.... While the Court will not assume jurisdiction to adjudicate on human rights disputes, it will not abdicate from exercising its jurisdiction of interpretation under Article 27 (1) merely because the reference includes allegation of human rights violation. ${ }^{44}$

At the time of inception, the Court of Justice of the European Union had very limited jurisdiction as well, as Karen J Alter said:

The ECJ was created to fill three limited roles for the member states: ensuring that the Commission and the Council of Ministers did not exceed their authority, filling vague aspects of EC laws through dispute resolution, and deciding on charges of non compliance raised by the Commission or member states. ${ }^{45}$

However, even with that limited jurisdiction, over time the CJEU asserted itself and provided guidance to the policy organs by interpreting the Treaty for prosperity. ${ }^{46}$ In the words of Alec Stone Sweet and James A. Caporaso:

The community treaties started as a set of legal arrangements binding on the member states but with a lot of help from the creative ECJ have evolved into a vertically integrated legal regime conferring legally

\footnotetext{
43 Reference No. 1 of 2007.

44 Ibid., typewritten judgment pp. 15-17.

45 Karen J Alter," Who are the Master of the Treaty"?: European Governments and the European Court of Justice, International Organization $5^{2}$ (1998) 121-147 p. 124.

See also EU Companion Chapters 4 and 9.
} 
enforceable rights and obligations on all persons and entities public and private within the EC territory. ${ }^{47}$

This was not achieved easily since the European Court was first and foremost established with limited roles, just like the EACJ.

The Court has also declined to entertain matters where its jurisdiction is in doubt. ${ }^{48}$ In Prof. Anyang' Nyongo and Others v. the Attorney General of the Republic of Kenya and Others, Ref. No.1 of 2006, the Court struck out the reference against two individuals for lack of capacity as they were wrongly sued. To clarify on whether a person can bring action under Article 30 against a natural person who commits misfeasance that infringe on provisions of the Treaty the Court held:

...A reference under Article 30 of the Treaty should not be construed as an action in tort brought by a person injured by or through the misfeasance of another. It is action to challenge the legality under the Treaty of an activity of a Partner State or of an institution of the Community. The alleged collusion and connivance, if any, is not actionable under Article 30 of the Treaty. 49

\subsubsection{Infringement Proceedings Initiated by a Partner State}

Ordinarily, infringement proceedings which are initiated by a Partner State, like those instituted by individuals, are ordinary suits that come to the Court by way of reference. ${ }^{50}$ As highlighted earlier in this chapter, a Partner State which considers that another Partner State or an organ or institution of the Community has infringed a provision of the Treaty, may refer the matter to the Court for adjudication. ${ }^{51}$ Furthermore, the Treaty gives power to a Partner

47 Alec Stone Sweet and James A.Caporaso, From Free Trade to Supranational Policy: The European Court and Integration in Waynes Sandholtz and Alec Stone Sweet (eds), European Integration and Supranational Governance, Oxford University, 1998, pp. 92-133 at p. 102.

48 Christopher Mtikila and Others v. The Attorney General of the United Republic of Tanzania, Ref No.2 of 2007.

49 Prof. Anyang' Nyongo and Others v. the Attorney General of the Republic of Kenya and Others, Ref. No.1 of 2006, page 7.

5o This term has no special meaning but it originates from the verb "refer" to represent and distinguish the cases in the East African Court of Justice with those in the national courts where such cases would be known as suits or claims.

$5^{1} \quad$ Article $28(1)$ of the Treaty, op. cit. 
State to refer for determination by the Court, the legality of any Act, regulation, directive, decision or action on the ground that it is ultra vires or unlawful or an infringement of the provisions of the Treaty or any rule of law relating to its application or amounts to a misuse or abuse of power. ${ }^{52}$

Despite the availability of this machinery, no single Partner State has ever dared bring action against another Partner State on ground of infringement of the Treaty. This inaction does not mean that there have not been Treaty infringements. ${ }^{53}$ Some infringements were, in fact, glaringly obvious. For example, the 2015 unfair and non-peaceful elections in the Republic of Burundi and the subsequent killings or disappearance of people who expressed dissatisfaction with the manner in which the entire election was conducted. Moreover, the post-2007 election violence in Kenya which led to the prosecution of the President and Vice President ${ }^{54}$ at the International Criminal Court, as well as the scramble for Mingigo Island between the Republics of Kenya and Uganda are further examples of unabated Treaty infringements.

\subsubsection{Infringement Proceedings Initiated by the Secretary General}

The Secretary General has powers to bring an action against a Partner State for infringement of the Treaty where he considers that a Partner State has failed to fulfil an obligation under the Treaty or has infringed a provision of the Treaty. ${ }^{55}$ However, the procedure for actualization of these powers by the Secretary General as laid down by the Treaty is cumbersome and makes it virtually impossible for him to exercise these powers. The Secretary General is required, before approaching the Court, to first submit his or her findings to the Partner State concerned so that Partner State can submit its observations on the findings by the Secretary General. ${ }^{56}$

If the Partner State concerned does not submit its observations to the Secretary General within four months, or if the observations submitted are unsatisfactory, the Secretary General shall refer the matter to the Council which shall decide whether the matter should be referred by the Secretary

\footnotetext{
$5^{2}$ Article $28(2)$ Ibid.

53 At one point the Republic of Kenya was about to go to war with the Republic of Uganda, a fellow Partner State quarreling for Migingu a rocky island in Lake Victoria. Even the Kenya 2007/08 post- election violence were never taken to the East African Court of Justice for their potential infringements of the Treaty until they found space in the ICC (The Hague) at the instance of the international community.

54 The charges against these Statesmen and top leaders of the Government of Kenya were subsequently dropped following lack of evidence.

55 Article 29 of the Treaty, op. cit.

56 Article 29 (1) of the Treaty Ibid.
} 
General to the Court immediately or be resolved by the Council. ${ }^{57}$ It is apparent that the Secretary General's powers to bring in Court an action for infringement of the Treaty against a Partner State is subject to two conditions: firstly; the Council should have failed to resolve the matter; and secondly, the Council, having failed to resolve the matter, should have directed the Secretary General to refer the matter to the Court. Short of that, the Secretary General cannot on his own imitative take action against a Partner State which infringes the Treaty. These conditions explain the non-existence of any reference by the Secretary General to date.

\subsection{Arbitration before the EACJ}

The EACJ can constitute itself as an arbitration tribunal. ${ }^{58}$ The Treaty confers arbitration mandate to the Court to the effect that:

The Court shall have jurisdiction to hear and determine any matter:

(a) arising from an arbitration clause contained in a contract or agreement which confers such jurisdiction to which the Community or any of its institutions is a party; or

(b) arising from a dispute between the Partner States regarding this Treaty if the dispute is submitted to it under a special agreement between the Partner States concerned; or

(c) arising from an arbitration clause contained in a commercial contract or agreement in which the parties have conferred jurisdiction on the Court. 59

The Court formulated the rules to govern arbitration proceedings after consulting its major stakeholders. These rules wait to be tested as soon as matters are referred to the Court for arbitration. It is a clear fact that, no arbitrator can arbitrate any matter unless the parties appoint him or include a clause in their agreement to the effect that in case of dispute they would all submit themselves to a certain arbitrator for arbitration.

57 Article 29 (2) of the Treaty, Ibid.

$5^{8}$ See also a discussion by John Eudes Ruhangisa, "Procedures and Functions of the East African Court of Justice", in Kennedy Gastorn, Harad Sippel and Ulrike Wanizek (eds), Processes of Legal Integration in the East African Community,-TGCL Series 2, Dar es Salaam University Press, Dar es Salaam, 2011, pp. 145-172.

Article 32 of the Treaty, op. cit. 
Although appointing the EACJ as arbitrator has many advantages vis-à-vis other arbitration fora, ${ }^{60}$ it is doubtful whether any parties have actually appointed it, as there has not been any litigation to compel the parties to choose the Court. Even the governments of the Partner States have not utilised the seemingly free services of the Court as far as arbitration is concerned but find it easier to go abroad and exclude an institution of their own creation. Lawyers in East Africa have a big role to play in advising their clients of the arbitral jurisdiction of the EACJ especially at the time of drafting commercial agreements.

There could be many reasons for this unusual reaction by the people of East Africa especially the business community. The wait and see tendency could be one of the possible reasons explaining the slow momentum in utilising the Court's arbitral jurisdiction. As the EACJ's arbitral jurisdiction is new, people may hesitate to risk filing their matters in the institute whose workings are unknown. Moreover, the double role being played by the Court, where on the one hand it functions as the Court of Justice and on the other hand as the arbitration tribunal, places it in difficult situation of making its stakeholders understand its definite status. Stakeholders would like to be assured that Judges sitting as arbitrators will behave differently from the way they behave while presiding over matters in court rooms, bearing in mind the fact that arbitration is a specialised discipline of dispute settlement. Arguably, the arbitral jurisdiction puts the eminence of the EACJ as a court of law at risk. Furthermore, the multiple jurisdictions of the Court as the Court of Justice, ${ }^{61}$ as a court of human rights, ${ }^{62}$ as a labour court ${ }^{63}$ and as an arbitration court ${ }^{64}$ may negatively impact on its efficiency should all these jurisdictions be fully operationalised.

Despite the Court's efforts in 2006 and thereafter to prepare itself for handling arbitration disputes by providing its Judges with arbitration skills through training, all such Judges have since retired without arbitrating any matter. As a result, the Court has to retrain Judges every time they complete their contractual tenure. The Court has spent a substantial amount of its financial resources to train the Judges who subsequently depart without leaving behind

\footnotetext{
6o Such advantages include the fact that parties to arbitration are not required to pay arbitrators' fee as the arbitrators are paid by East African Community in their capacities as Judges.

61 Article 27 of the Treaty, op. cit.

62 Article 27 (2) Ibid.

63 Article 31, Ibid.

64 Article 32, Ibid.
} 
the fruits of such investment. In effect, the Court has been turned into a training ground for arbitrators who do not benefit it. Since 2001, when the Court was inaugurated, only one case, Nayebare Alice v. East Africa Law Society, ${ }^{65}$ has been arbitrated. The Claimant's claim was for a total sum of USD 48,387.00, which constituted payment for various employment benefits covering salary emoluments, leave and repatriation allowances, sundry and other termination benefits. In addition, the Claimant prayed for an order that: "the Respondent clears and/or signs the requisite NSSF forms to enable the Claimant access her NSSF savings." The arbitral claim was heard and an award given on gth May 2014 to the effect that the Claimant was entitled to a monetary award of USD 8,534 plus interest on the amount at the Tanzanian rate from 9th May, 2014 until payment in full and that the Respondent should within 7 days of the award remit USD 724.50 to NSSF as its contribution for the claimant, covering a period between September-December 2004.

\subsection{Advisory Opinions of the EACJ}

The Treaty confers jurisdiction on the Court to give advisory opinions regarding a question of law arising from the Treaty which affects the Community. ${ }^{66}$ This is a rare, if not inexistent, in municipal jurisdiction in common law countries. It was however, sourced from the Court of Justice of the European Union (itself largely of the continental legal systems). ${ }^{67}$ Among the organs and institutions of the Community, it is only the Council of Ministers that may request advisory opinions from the Court. ${ }^{68}$ It makes sense to make the request for advisory opinions one of the functions of the Council of Ministers which is the policy organ of the Community. However, what is objectionable is to make the Council of Ministers the only and sole organ which can request advisory opinions from the Court. The Council is not an active and operational executive arm of the Community and therefore unable to encounter issues which may require the Court's interpretation or advisory opinion. Ordinarily, it is only issues of policy nature about which the Council may require the Court's opinion. The implementation of the Treaty and the decisions of the executive organs of the Community is the responsibility of the Secretary General.

\footnotetext{
65 Arbitration Cause No. 1 of 2012.

66 Article 36, Ibid.

67 See Eu Chapter 7 .

68 Article 14 (4) of the Treaty, op. cit.
} 
However, paradoxically, the Secretary General who in the course of executing his duties is likely to encounter challenges that may necessitate judicial pronouncement by way of advisory opinion, has no powers to approach the Court for advisory opinion on any matter. It can be argued that such powers for seeking advisory opinion could be given to the Assembly provided due regard is taken to preserve separation of powers among these two organs. As a result, the Council of Ministers has been hesitant to approach the Court for an advisory opinion although there have been disagreements especially at Council level which the Court would have given its advisory opinion if approached.

Bearing in mind the seriousness of such issues, should advisory opinions be rendered by Court of First Instance, subject to appeal to the Appellate Division or by the Appellate Division, whose decisions are final? There is no guidance in the Treaty on this issue so the Court took a decision to put a request for an advisory opinion, within the jurisdiction of the Appellate Division due to the fact that it is not appealable. Rule 75 (1) of the EACJ Rules of Procedure was introduced to the effect that:

A request for an advisory opinion under Article 36 of the Treaty shall be lodged in the Appellate Division and shall contain an exact statement of the question upon which an opinion is required and shall be accompanied by all relevant documents likely to be of assistance to the Division.

This was yet another stop-gap measure taken by the Court to fill a void.

Only two cases, Advisory Opinion No. 1 of 2008 In the matter of a Request by the Council of Ministers of the East African Community for an Advisory Opinion and Advisory Opinion No. 2 of 2015 In the matter of a Request by the Council of Ministers of the East African Community for an Advisory Opinion have since been referred to the EACJ by the Council of Ministers.

In the first request the issues were whether the principle of variable geometry ${ }^{69}$ was in harmony with the requirement for consensus in decisionmaking and whether the principle of variable geometry could apply to guide the integration process, notwithstanding the requirement on consensus in decision-making by the Community's top organs (Summit of EAC Heads of State, and Council of Ministers). The First Instance Division of the Court delivered its opinion on 24th April 2009 that the principle of variable geometry is

69 Under the principle of "Variable Geometry", groups within the East African Community are allowed progression in cooperation for wider integration schemes in different fields and at different speeds. See Article 7 (1) of the Treaty. 
in harmony with the requirement for consensus in the decision-making process of the EAC organs. Consensus is a purely decision-making mechanism; while variable geometry is a strategy for implementation of the decisions so made (bearing in mind the capacity of each Partner State to implement the particular decisions). Consensus does not mean unanimity when used in the EAC Treaty.

As for the second and most current request which is pending a ruling on 19th November 2015, the issue was whether forfeiture of a position of a Deputy Secretary General by a Partner State under Article 67(2) of the Treaty for the purpose of making way for an incoming Secretary General from the same Partner State was in effect a withdrawal of such Deputy Secretary General.

The procedure for advisory opinions represents another dormant potential, waiting to be tapped, not only to resolve substantive questions of law that arise, but also to engage the Court which is waiting to contribute to the lively jurisprudence of the region.

\subsection{Conclusion}

Regional integration has become the world's major inclination due to the effect of globalization. Africa as a continent and East Africa as a sub region has not been left out in this crusade due to the forces that dictate the prevailing world dimension. If any regional integration is to succeed those who are involved in the process should appreciate the need for building strong institutions instead of banking on the rarely available strong individuals to spearhead the process. Whereas effective and strong institutions can endure indefinitely, effective individual leaders come and go.

The EAC model of integration is unique in that it is structured as a State and aims ultimately to become a political federation. All its organs and institutions are working towards the achievement of this challenging goal. The EACJ for its part is participating in the process by providing judicial interpretation of the Treaty and other Community laws and in ensuring respect for the founding principles of the Community. Its jurisprudence so far has proven that the Court has modeled itself to the standards of a respectable and independent organ that encourages public interest litigation.

The peoples of East Africa should know that the integration process on which the EAC has embarked is for them. The rights that flow from the Treaty are for them. They should enjoy them and claim them where necessary through the regional justice mechanism put in place by the Treaty as the Court attempts to create an environment conducive to public interest litigation. 
The discussion in this topic has highlighted the judicial protection mechanisms under the Treaty within EAC framework. A section of the population has attempted to seek remedy and realize the rights afforded to them by the Treaty. However, reflecting on the discussion above, it may be questioned as to whether the existing judicial protection mechanisms are as effective as they could or should be. 